\title{
The Dynamics of Relation Oat Panicle with Grain Yield by Nitrogen
}

\author{
Rubia Diana Mantai1, José Antonio Gonzalez da Silva², Emilio Ghisleni Arenhardt, \\ Airam Tereza Zago Romcy Sausen1, Manuel Osório Binello1, Vidica Bianchi', \\ Dionatas Rodrigues da Silva ${ }^{2}$, Luiz Michel Bandeira ${ }^{2}$ \\ ${ }^{1}$ Department of Exact Sciences and Engineering, Regional University of the Northwest of Rio Grande do Sul \\ State, ljuí, Brazil \\ ${ }^{2}$ Department of Agrarian Studies, Regional University of the Northwest of Rio Grande do Sul State, Ijuí, Brazil \\ ${ }^{3}$ Department of Crop Plants, Federal University of Rio Grande do Sul, Porto Alegre, Brazil \\ ${ }^{4}$ Department of Life Sciences, Regional University of the Northwest of Rio Grande do Sul State, Ijuí, Brazil \\ Email: emilio.arenhardt@yahoo.com.br
}

Received 19 November 2015; accepted 5 January 2016; published 8 January 2016

Copyright (C) 2016 by authors and Scientific Research Publishing Inc.

This work is licensed under the Creative Commons Attribution International License (CC BY). http://creativecommons.org/licenses/by/4.0/

c) (7) Open Access

\section{Abstract}

The oat panicle components were changed by the forms of nitrogen use influencing productivity. The aim of the study was to determine the direct and indirect effects of oat panicle components on grain yield by $\mathrm{N}$-fertilizer rates in succession systems of high and reduced release of $\mathrm{N}$-residual. The study was conducted in the years 2013 and 2014 in a randomized complete block with four replications in a factorial $3 \times 2$, for nitrogen rates $\left(30,60\right.$ and $\left.120 \mathrm{~kg} \cdot \mathrm{ha}^{-1}\right)$ and oat cultivars (Barbarasul and Brisasul) the soybean/oat and corn/oat systems. The panicle weight and grain per panicle show greater sensitivity to the change of nitrogen rates. Grain yield was favored by the direct effect of harvest index panicle and indirect by grain weight per panicle. In the system soybean/oat, the grain weight of panicle shows greater efficiency in promoting positive direct effects on grain yield.

\section{Keywords}

Avena sativa L., Ureia, Relation C/N, Correlation and Path Analysis

\section{Introduction}

The winter crop rotation is a common practice in agricultural production, essential for the development of a more sustainable agriculture [1]. Oats represent an excellent alternative to diversification and economic contri- 
bution of the production system, either by covering and protecting the soil and use in feed and food [2] [3].

The grain yield in oats is incremented with the increased availability of nitrogen, promoting effects that alter the expression of yield components [4]. Proper use of fertilizer in agriculture can promote high quality and productivity, or losses, when the occurrence of the lodging and loss by volatilization and leaching [3] [5]. The type of vegetative cover also influences the losses by leaching or volatilization, and the nitrogen use efficiency [5] [6]. Therefore, the biochemical composition of residues affects the choice of proper dose and time of nitrogen supply, taking into account the nutrient release rate into the soil and the decomposing tissues [7]. The correct nitrogen management highlights the need to meet the dynamics of use by oats at elaboration of the yield components [8]. In this way, the association of grain yield with the components of the inflorescence represents a strategy that can optimize forms of nutrient use [9]. In the understanding and sizing of cause and effect relationships, path analysis has been used in the study of various species, as example, oat [10], wheat [11], soybean [12], sunflower [8] among others. This method is based on evaluation of the effect of an independent variable $(\mathrm{x})$ over a dependent variable $(\mathrm{y})$, after removing the influence of all other independent variables [11].

The aim of the study is to determine the direct and indirect effects of oat panicle components on grain yield by $\mathrm{N}$-fertilizer rates in succession systems of high and reduced release of $\mathrm{N}$-residual.

\section{Material and Methods}

The field experiments with oats were conducted in Augusto Pestana, RS, Brazil (28 $26^{\prime} 30^{\prime \prime}$ South latitude and 54 $04^{\circ} 58^{\prime \prime}$ West longitude), in 2013 and 2014 years. The soil of the area is classified as Oxisol Distroferric Typical and the climate, according to Köppen classification is temperate humid with hot summer, without dry season. Soil analysis ten days before oats sowings identified the following chemical characteristics of the local: i) corn/oat system $\left(\mathrm{pH}=6.5, \mathrm{P}=34.4 \mathrm{mg} \cdot \mathrm{dm}^{-3}, \mathrm{~K}=262 \mathrm{mg} \cdot \mathrm{dm}^{-3}\right.$, Organic Matter $=3.5 \%, \mathrm{Al}=0.0 \mathrm{cmol}_{\mathrm{c}} \cdot \mathrm{dm}^{-3}$, $\left.\mathrm{Ca}=6.6 \mathrm{cmol}_{\mathrm{c}} \cdot \mathrm{dm}^{-3} ; \mathrm{Mg}=3.4 \mathrm{cmol}_{\mathrm{c}} \cdot \mathrm{dm}^{-3}\right)$ and; ii) soybean/oat system $\left(\mathrm{pH}=6.2, \mathrm{P}=33.9 \mathrm{mg} \cdot \mathrm{dm}^{-3}, \mathrm{~K}=200\right.$ $\mathrm{mg} \cdot \mathrm{dm}^{-3}$, Organic Matter $\left.=3.4 \%, \mathrm{Al}=0.0 \mathrm{cmol}_{\mathrm{c}} \cdot \mathrm{dm}^{-3}, \mathrm{Ca}=6.5 \mathrm{cmol}_{\mathrm{c}} \cdot \mathrm{dm}^{-3} ; \mathrm{Mg}=2.5 \mathrm{cmol}_{\mathrm{c}} \cdot \mathrm{dm}^{-3}\right)$. In both experimental years, oats was sown in optimal time, i.e. in the first week of June with seeder-fertilizer. Each plot consisted of 5 rows of $5 \mathrm{~m}$ length with $0.20 \mathrm{~m}$ line space, forming the experimental unit $5 \mathrm{~m}^{2}$. During the vegetation period oats was protected from diseases by FOLICUR ${ }^{\circledR}$ CE tebuconazole fungicide applications at the dose of $0.75 \mathrm{~L} \cdot h a^{-1}$ and from weeds control by $\mathrm{ALLY}^{\circledR}$ metsulfuron-methyl herbicide, at the dose of $2.4 \mathrm{~g} \cdot \mathrm{ha} \mathrm{a}^{-1}$ of the active ingredient and manual weeding when necessary. At the time of oat sowing, was used NPK formulation (5-20-20), with nitrogen base of $10 \mathrm{~kg} \cdot \mathrm{ha}^{-1}$ (except in the standard experimental unit) and 60 and 50 $\mathrm{kg} \cdot \mathrm{ha}^{-1}$ of $\mathrm{P}_{2} \mathrm{O}_{5}$ and $\mathrm{K}_{2} \mathrm{O}$ applied, respectively, based on the levels of organic matter, $\mathrm{P}$ and $\mathrm{K}$ in the soil to expected grain yield of about of $3 \mathrm{t} \cdot \mathrm{ha}^{-1}$. The rest of the nitrogen to contemplate the remaining doses was applied in coverage with urea $(45 \% \mathrm{~N})$, in four oat leaf stage.

The experimental design was randomized blocks with four repetitions, in factorial scheme $3 \times 2$ for N-fertilizer rates (30, 60 and $120 \mathrm{~kg} \cdot \mathrm{ha}^{-1}$ ) and Oat cultivars (Barbarasul and Brisasul), respectively, totaling 24 experimental units for crop successions of high and reduced relation $\mathrm{C} / \mathrm{N}$ (corn/oat and soybean/oat system). For that purpose oats harvested manually from three central rows of each plot at the maturity (grain moisture about 22\%). Then threshed with a stationary thresher and dried to the $13 \%$ grain moisture, in addition to weighing to estimate the grain yield (GY, kg.per $\cdot \mathrm{ha}^{-1}$ ). In the analysis of panicle components, there was the random collection of 20 oat panicles per experimental unit, that they were directed to the laboratory for grain moisture correction by $13 \%$, and subsequent decomposition of inflorescence components (Figure 1). Therefore, it was measured panicle length (PL, cm), number spikelet per panicle (NSP, n), number grain per panicle (NGP, n), panicle weight (PW, g), grain weight per panicle (GWP, g) and harvest index panicle (HIP, g. $\mathrm{g}^{-1}$ ) given by the relation $\frac{\text { GWP }}{\text { PW }}$.

The homogeneity and normality was checked by Bartlett test [13], after the analysis of variance was performed to detect the main and interaction effects. Although evidenced the presence of interaction, the effects to estimate the relative contribution by the nitrogen rates were dimensioned by agricultural year by the joint effect of cultivars, because it are inferences to be generalized about this specie and not a specific cultivar. Was performed means analysis in each nitrogen rates to the main variable grain yield by means clustering Scott \& Knott method. It was performed relative contribution analysis by the effect of nitrogen by Mahalanobis distance [14], 


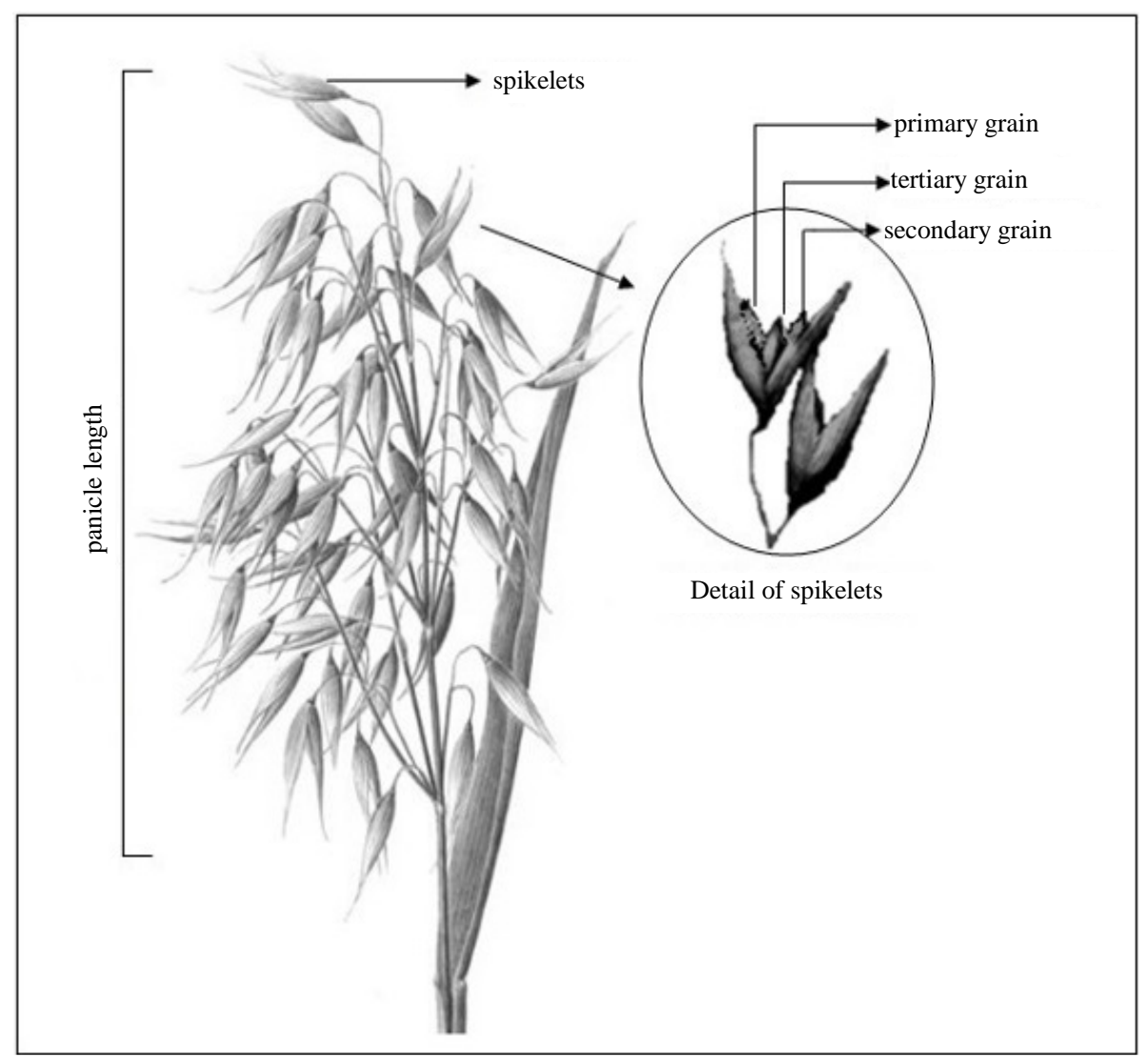

Figure 1. Detail panicle of white oat, basis of analysis for decomposition of the inflorescence components.

which allows to estimate the contribution of each variable front the total variability observed. The relative contribution was evaluated by Singh method based on statistical $S_{j}[15]$. Thus it has been:

$$
D_{i i^{\prime}}^{2}=\delta^{\prime} \psi^{-1} \delta=\sum_{j=1}^{n} \sum_{j^{\prime}=1}^{n} \omega_{i j j^{\prime}} d_{j} d_{j^{\prime}}
$$

on what:

- $\quad D_{i i^{\prime}}^{2}$ : Mahalanobis distance between treatments $i$ and $i$;

- $\psi$ : Matrix of variances and covariances residuals;

- $\delta^{\prime}=\left[d_{1}, d_{2}, \cdots, d_{n}\right]$, being $d_{j}=Y_{i j}-Y_{i^{\prime} j}$

- $Y_{i j}$ : Mean of $i$-th rate in relation to the $j$-th trait

- $\omega$ : Element in the $j$-th row e $j$ '-th column of the inverse of matrix of variances and covariance residuals.

The total of the distances involving all pairs of treatments is given by:

$$
\sum_{i<} \sum_{i^{\prime}} D_{i i^{\prime}}^{2}=\sum_{m} D_{m}^{2}=\sum_{j=1} S_{. j}
$$

The $S_{j}$ values percentages are a measure of the relative importance of the variable.

It was determined the magnitude and direction of correlations between grain yield and oat panicle components. The hypotheses were tested at level 5\% probability of error adopting the $t$ test, considering $n-2$ degrees of freedom and following the model $t=r /\left[\sqrt{\left(1-r^{2}\right)} /(n-2)\right]$, being $r$ the coefficient of correlation between traits $X$ and $Y$; and $n$ = degrees of freedom in levels considered treatments. After it was performed path analysis to detect direct and indirect effects of the variables on grain yield in the supply of nitrogen rates by cropping systems. As the phenotypic correlation includes both parts attributed to genetic or environmental effects, the inclusion of sources of variation for both effects, allowed knowing with greater fidelity the strength of these rela- 
tions [16]. Therefore, in this analysis, was considered the combined effect of years and cultivars for further decomposition of direct and indirect effects by path analysis. Being $Y$ (grain yield) the main variable resulting from the combined effect of other variables (panicle components), is obtained the following model:

$$
Y=\beta_{1} X_{1}+\beta_{2} X_{2}+\cdots+\beta_{n} X_{n}+\varepsilon
$$

where $X_{1}, X_{2}, \cdots, X_{n}$ are explanatory variables and $\mathrm{Y}$ the main variable (or dependent). Considering,

$$
y=\frac{Y-\bar{Y}}{\hat{\sigma}_{y}} \quad x=\frac{X_{i}-\bar{X}_{i}}{\hat{\sigma}_{x i}} \quad u=\frac{\varepsilon}{\hat{\sigma}_{\varepsilon}} \quad p=\frac{\hat{\sigma}_{\varepsilon}}{\hat{\sigma}_{y}} \quad p_{o i}=\frac{b_{o i} \hat{\sigma}_{x i}}{\hat{\sigma}_{y}}
$$

It has,

$$
y=p_{1} x_{1}+p_{2} x_{2}+\cdots+p_{n} x_{n}+p_{\varepsilon} u
$$

For this model, were estimated the direct and indirect effects of the explanatory variables on the main variable. The path coefficients were estimated from the system of equations $X^{\prime} X \hat{\beta}=X^{\prime} Y$, being:

$$
X^{\prime} Y=\left[\begin{array}{c}
r_{1 y} \\
r_{2 y} \\
\vdots \\
r_{n y}
\end{array}\right] \quad X^{\prime} X=\left[\begin{array}{cccc}
1 & r_{12} & \cdots & r_{1 n} \\
r_{12} & 1 & \cdots & r_{2 n} \\
\cdots & \cdots & \cdots & \cdots \\
r_{1 n} & r_{2 n} & \cdots & 1
\end{array}\right] \text { and } \hat{\beta}=\left[\begin{array}{c}
p_{1} \\
p_{2} \\
\vdots \\
p_{n}
\end{array}\right]
$$

Thus,

$$
r_{i j}=p_{i}+\sum_{j \neq 1}^{n} p_{j} r_{i j}
$$

where:

$r_{i j}$ : Correlation between the main variable (y) and the $i$-th explanatory variable;

$p_{i}$ : Measurement the direct effect of variable i on the main variable;

$p_{j} r_{i j}$ : Measurement the indirect effect of the variable $i$, by variable $j$, on the main variable.

The coefficient of determination of the path diagram is given by:

$$
R^{2}=p_{2} r_{1 y}+p_{2} r_{2 y}+\cdots+p_{n} r_{n y}
$$

and the residual effect is estimated by:

$$
\hat{p}_{\varepsilon}=\sqrt{1-R^{2}}
$$

All analyzes were performed using the GENES software [17].

\section{Results and Discussion}

In Table 1, the means values in the soybean/oat system in 2013 indicate an increase in the expression of variables in dose of $60 \mathrm{~kg} \mathrm{~N} \mathrm{ha}^{-1}$ in comparison with the higher and reduced rates, including, with means difference in grain yield. This condition has also been observed in most of the variables in the corn/wheat system, although the grain yield has not changed in 60 and $120 \mathrm{~kg} \cdot \mathrm{ha}^{-1}$ of nitrogen. It should be noted the higher mean yield values and other components oat panicle in soybean/oat over corn/oat system. This strengthens the importance of the system of succession of lower $\mathrm{C} / \mathrm{N}$ ratio, providing higher $\mathrm{N}$-residual, particularly for smaller fertilization conditions. The type of plant residue affects the efficiency utilization of nitrogen fertilization the culture in succession [18]. The productivity of biomass and oat grains has shown favored by soybean/oats system, reducing the dependence of nitrogenous fertilizer and the cost of production [4]. The inadequate management of nitrogen fertilization has been one of the factors that have limited the increase in grain productivity in Brazil [19]. In wheat grown on soybean residue, benefits of the N-residual in spike components has been observed, with reflections on productivity [20]. 
Table 1. Means and relative contribution per year and nitrogen rate on grain yield and panicle components oat per system of succession.

\begin{tabular}{|c|c|c|c|c|c|c|c|c|}
\hline \multirow{3}{*}{$\mathrm{Y}$} & \multicolumn{6}{|c|}{ Means Values } & \multicolumn{2}{|c|}{ Contribution (\%) } \\
\hline & \multicolumn{3}{|c|}{2013} & \multicolumn{3}{|c|}{2014} & \multirow{2}{*}{2013} & \multirow{2}{*}{2014} \\
\hline & 30 & 60 & 120 & 30 & 60 & 120 & & \\
\hline \multicolumn{9}{|c|}{ soybean/oat system } \\
\hline GY & В3693 & A4123 & В3537 & А3060 & A3051 & A2954 & 6.63 & 1.27 \\
\hline PW & 2.65 & 2.72 & 2.42 & 2.84 & 2.97 & 3.05 & 38.91 & 24.25 \\
\hline GWP & 2.33 & 2.38 & 2.10 & 1.80 & 1.91 & 1.97 & 43.54 & 25.93 \\
\hline NSP & 39 & 45 & 42 & 42 & 44 & 49 & 4.59 & 29.14 \\
\hline NGP & 73 & 78 & 71 & 77 & 82 & 89 & 0.03 & 3.82 \\
\hline PL & 19.01 & 19.53 & 19.46 & 19.90 & 20.80 & 20.06 & 0.85 & 13.99 \\
\hline HIP & 0.87 & 0.87 & 0.86 & 0.63 & 0.63 & 0.64 & 5.41 & 1.57 \\
\hline \multicolumn{9}{|c|}{ corn/oat system } \\
\hline GY & B2583 & А3003 & A2821 & B2492 & A2827 & А3019 & 7.30 & 5.03 \\
\hline PW & 2.21 & 2.37 & 1.94 & 2.87 & 3.22 & 3.36 & 37.70 & 19.10 \\
\hline GWP & 1.88 & 2.08 & 1.65 & 1.76 & 2.16 & 2.25 & 36.99 & 41.32 \\
\hline NSP & 35 & 40 & 37 & 45 & 52 & 54 & 10.67 & 2.82 \\
\hline NGP & 68 & 73 & 62 & 81 & 94 & 100 & 0.83 & 3.18 \\
\hline PL & 18.28 & 18.05 & 18.46 & 19.90 & 19.98 & 20.88 & 0.92 & 0.12 \\
\hline HIP & 0.84 & 0.87 & 0.84 & 0.61 & 0.66 & 0.66 & 5.56 & 28.39 \\
\hline
\end{tabular}

$\mathrm{Y}=$ variable; $\mathrm{GY}=$ grain yield $\left(\mathrm{kg} \cdot \mathrm{ha}^{-1}\right)$; PW = panicle weight $(\mathrm{g})$; GWP = grain weight per panicle (g); NSP = number spikelet per panicle (n); NGP = number grains per panicle $(\mathrm{n})$; PL = panicle length $(\mathrm{cm})$; HIP = harvest index panicle (GWP/PW g.g ${ }^{-1}$ ). Means followed by the same capital letter in the line does not differ from each other by the Scott \& Knott test at 5\% probability of error.

In Table 1, in the year 2014 in soybean/oat system, increased rates of $\mathrm{N}$-fertilizer not promoted benefits on income of grain. On the other hand, in the corn/oat system, the rate $60 \mathrm{~kg} \cdot \mathrm{ha}^{-1}$ of nitrogen promoted greater productivity, however, behavior similar to the highest dose of the nutrient. Highlights that in most variables, there was an increase in the mean in the highest rate, regardless of cropping system. It stands out in 2013 the occurrence of milder temperatures and better rainfall distribution favoring the expression of panicle components reflected in higher grain yield. In addition, in 2014, excessive rains at the end of the cycle contributed less variable expression (Figure 2).

At the reference [21] positive responses were obtained on the yield and oat panicle components in the increment of $\mathrm{N}$-fertilizer in more restrictive conditions. The yield and wheat spike components were increased by higher $\mathrm{N}$-fertilizer rate, with more pronounced effects on the number of spikes per unit area and grains per spike [22]. Research in white oat indicates that grain yield shows quantitative inheritance with direct and indirect action of subcomponents related [3]. The oat grain yield is a result set of various components, such as total biomass, panicle weight, number grain per panicle, among others. Therefore, individual modifications and/or in combination that can increase or reduce the final yield [23].

In Table 1, the relative contribution analysis, the breakdown of the total variability by nitrogen rates highlights in 2013 in the soybean/oat system, the greatest contribution of modification by the panicle weight and of grain panicle. In the year 2014, also these are the variables that have expressed greater contribution by the number spikelet per panicle. Thus, the changes that take place by the increase in fertilizer levels in this condition of cultivation, qualify the grain weight and panicle as the greater variation sensitivity. A relevant fact in corn/oat system in 2013 was also the largest relative contribution by the panicle weight and grain of panicle to answer the 
Year 2013

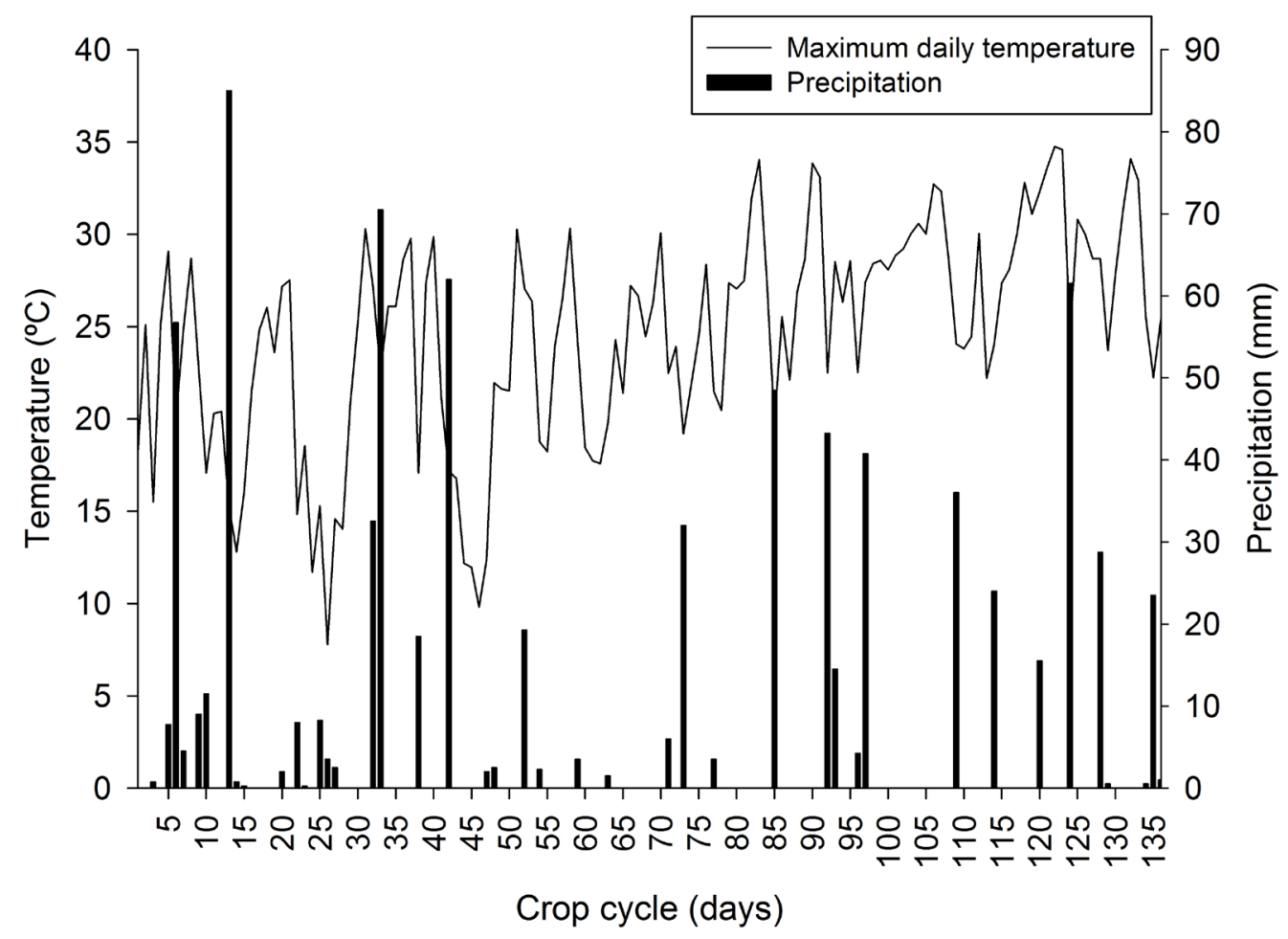

Year 2014

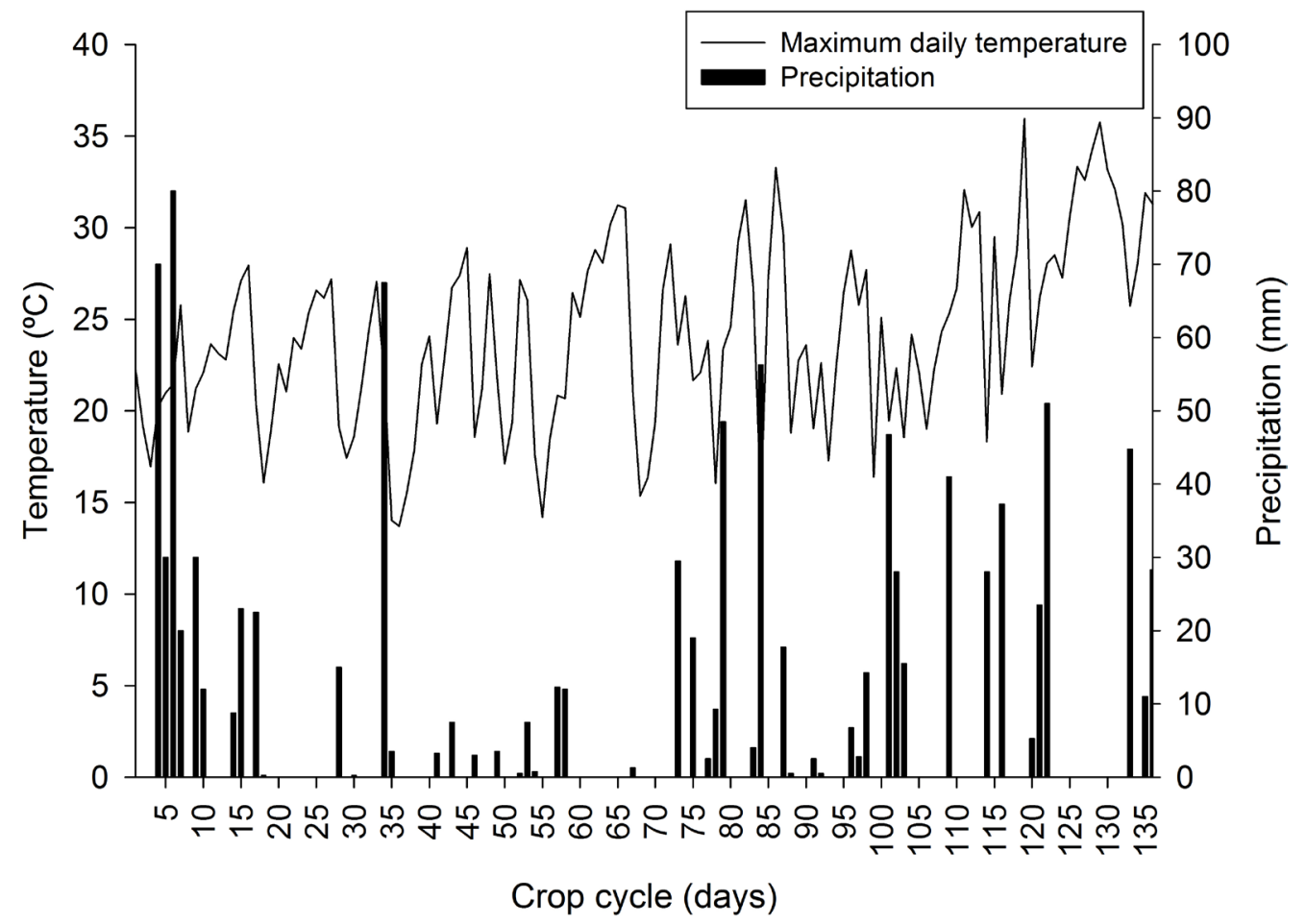

Figure 2. Climatological data of different years of study. 
nitrogen rate (Table 1). However, either on soybean/oat or corn/oat system, regardless of cultivation years, the grain weight per panicle proved to be the most responsive changes by fertilizing. Note that as the nitrogen was being incremented, changes in contribution will happening. In 2014 the corn/oat system, a significant magnitude was obtained by the panicle weight, however, lower than the observed by index of panicle harvesting. The relative contribution analysis allows knowing the traits that contribute most to the total variability [2]. Research [24] reports that in Sudangrass, there is the possibility identification of plants more efficient to use environmental stimuli by panicle weight and number grain per panicle. [25] studying oats, also found in the panicle weight the greatest contribution in the identification of plants with higher grain yield variability observed in inflorescence components. According to these same authors, the number grain per panicle and grain weight per panicle were also effective in differentiating more desirable genotypes. In wheat, observed that the weight spike and the number grains per spike were the variables that contribute most of the observed differences in inflorescence [26].

In Table 2 the correlation and path analysis in soybean/oat system, although the panicle weight is the component of the inflorescence with major change by the dose of nitrogen (Table 1), the correlation of grain yield with

Table 2. Correlation and path analysis of grain yield and oat panicle components in doses of nitrogen in soybean/oat system.

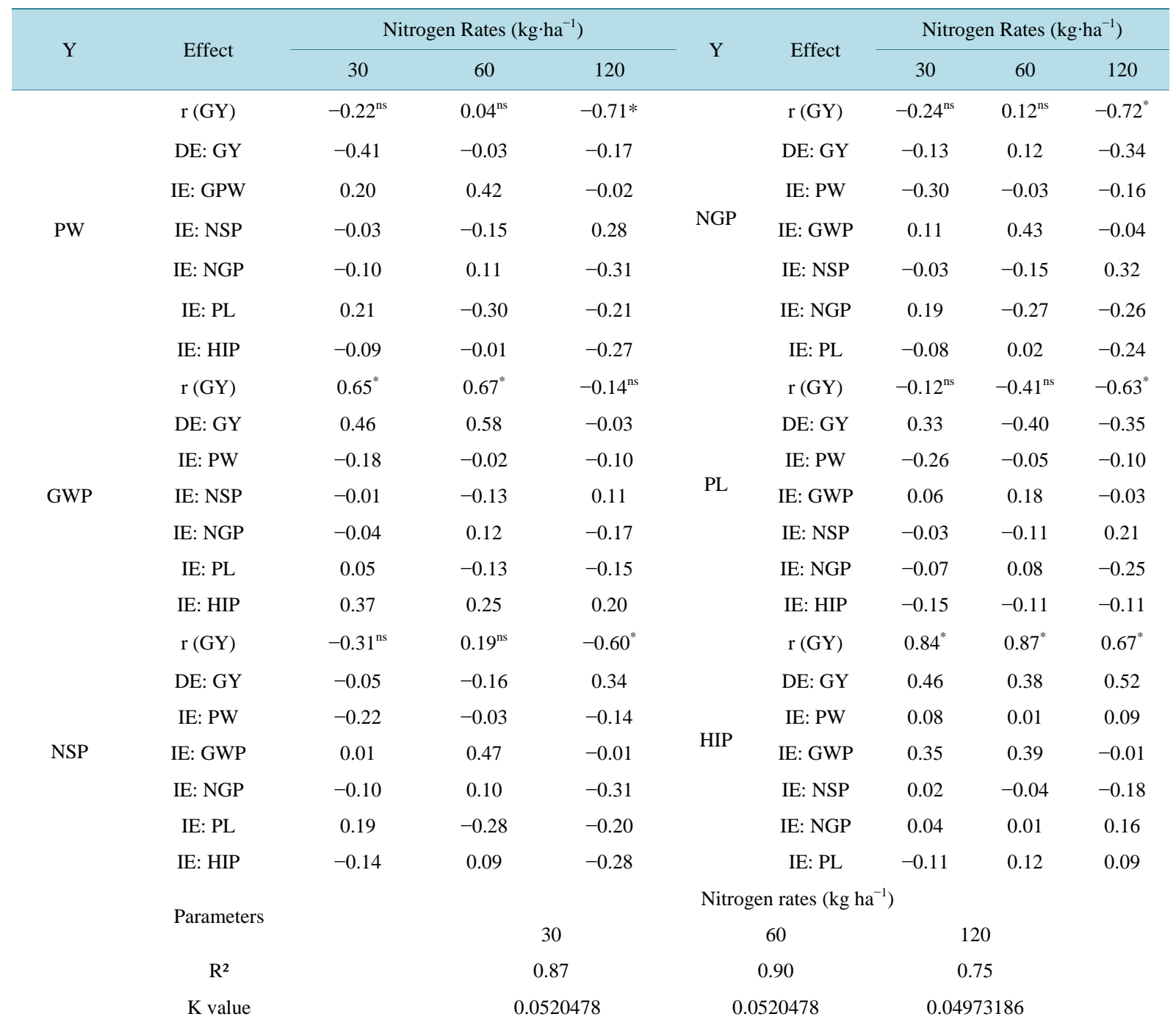

$\mathrm{Y}=$ variable; $\mathrm{GY}=$ grain yield $\left(\mathrm{kg} \cdot \mathrm{ha}^{-1}\right)$; PW = panicle weight $(\mathrm{g})$; GWP = grain weight per panicle (g); NSP = number spikelet per panicle (n); NGP = number grains per panicle $(\mathrm{n}) ; \mathrm{PL}=$ panicle length $(\mathrm{cm})$; HIP = harvest index panicle $\left(\mathrm{GWP} / \mathrm{PW} \mathrm{g}^{-1} \mathrm{~g}^{-1}\right)$. $\mathrm{r}=$ correlation; DE $=$ direct effect; $\mathrm{IE}=$ indirect effect; $\mathrm{R}^{2}=$ coefficient of determination; $\mathrm{k}=$ coefficient of linearization; ${ }^{*}=$ Significant at $5 \%$ probability of error by the test; ns = not significant. 
the panicle weight was not observed in reduced and intermediate N-fertilizer rate. Even under these conditions (30 and $60 \mathrm{~kg} \cdot \mathrm{ha}^{-1}$ of nitrogen), the grain yield also showed no relationship on the number spikelet per panicle, number grains per panicle and panicle length. These results seem to indicate that system easy N-residual release (soybean/oat) had already brought favoring the expression of these variables, not allowing for changes in these $\mathrm{N}$-fertilizer rates. This hypothesis is strengthened seen that in the condition more higher of the nutrient, we obtained negative correlation between the panicle weight, number spikelet per panicle, number grains per panicle and length panicle with grain yield. This negative correlation showed that the decomposition in path analysis at $120 \mathrm{~kg} \cdot \mathrm{ha}^{-1}$ of nitrogen, the vast majority of the variables presented elevated indirect negative contribution by harvest index panicle, panicle length and number grain per panicle, and direct effect by grain yield (Table 2).

The study of correlated traits can favor the choice of genotypes and/or handlings more adjusted, provided that is positively show linked to grain yield [27]. However, the correlations by itself does not inform about the cause-and-effect relationship between the explanatory variables and the main, suggesting the decomposition of these relations via track analysis [28]. Reference [10] studying oat populations have noted that the number grains per panicle was the component that most contributed about the correlation of the weight panicle with the grain yield, justifying that the grains account for $80 \%$ to $85 \%$ of the total weight panicle. In oat cultivars in Mongolia the grain yield proved to be dependent on the weight panicle and number grain per panicle, corroborating in positive correlations with grain yield [29]. [28] studying wheat under different conditions of fertilization found a greater effect on the weight grain component, with direct effect in raising grain yield. In wheat was identified correlations between grain yield and number spikelet per plant, showing that more productive plants presented indirect effect by number grains per spike [30].

In Table 2, the correlation of grain yield with the grain weight per panicle highlighted a significant and positive relation in 30 and $60 \mathrm{~kg} \cdot \mathrm{ha}^{-1}$ of nitrogen. These associations bring with them a high direct effect for grain yield and indirect by harvest index panicle. However, the absence of correlation in the highest rate brings subsidies to suggest that in this condition, the ability of nitrogen utilization by oats had already been obtained, not allowing maintenance of the linear relation. A relevant fact was the positive direct correlation of grain yield with harvest index panicle, bringing this contribution in all fertilization conditions. In addition, such contribution is favored both for the direct effect by grain yield in different fertilization as the indirect effect by weight grains per panicle to the 30 and $60 \mathrm{~kg} \cdot \mathrm{ha}^{-1}$ of nitrogen. [31] also found a correlation of grain yield with grain weight per panicle, even with similar magnitude value $(r=0.60)$. Significant positive correlation of grain yield with grain weight per panicle and number grain per panicle was found by [2]. According to [32] nitrogen use efficiency in beans varied with the nitrogen rates in the analysis of harvest index, where the agronomic efficacy was decreased with increasing rate. In rice cropping, the increased harvest index and grain weight provides high correlations with grain yield, suggesting variable selection of more productive plants [33].

In Table 3, the correlation and path analysis on corn residue, relevant fact was the lack of correlation with grain yield among all tested variables, whether in low or high N-fertilizer condition. Therefore, raises the hypothesis that the reduced fertilization in restrictive condition of N-residual, not allowed differentiation in panicle traits. Furthermore, in the higher fertilizer rate, has been reached the maximum nutrient absorption capacity, not providing possible correlations in these conditions. These hypothesis are reinforced by the presence of correla-

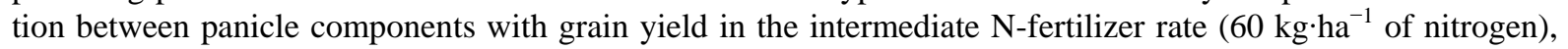
only except for grain weight per panicle. Nitrogen rates in the corn/wheat system exert significant effects on grain yield, and the inflorescence components changed by thousand grain weight and grain weight per spike [9]. According to [23] is extremely important the relations that occur on weight of the oat panicle, because it includes both the number of grains as the weight grains, which are decisive on the final yield of the species.

In Table 3, the rate of $60 \mathrm{~kg} \cdot \mathrm{ha}^{-1}$ of $\mathrm{N}$-fertilizer showed negative correlation of grain yield with the panicle weight, number grains per panicle and panicle length, with large negative indirect contribution of the number spikelet per panicle. This result is reinforced in view of the existing negative correlation between grain yield and the number spikelet per panicle, promoting large negative direct effect by grain yield. Therefore, assume that new genotypes with an increase in the number spikelet per panicle can bring significant changes in a more restrictive condition of N-residual. Emphasize the positive correlation of grain yield with harvest index panicle, mainly by the positive indirect effect of grain panicle weight, condition also verified in the soybean/oat system (Table 2). On the other hand, the grain weight per panicle not bring significant benefits when considering the corn/oat system. Studying levels of nitrogen and potassium on oats, [34] verified that the different levels of fertilizer could significantly increase the number spikelet per panicle, panicle length and the panicle weight, 
Table 3. Correlation and path analysis of grain yield and oat panicle components in doses of nitrogen in corn/oat system.

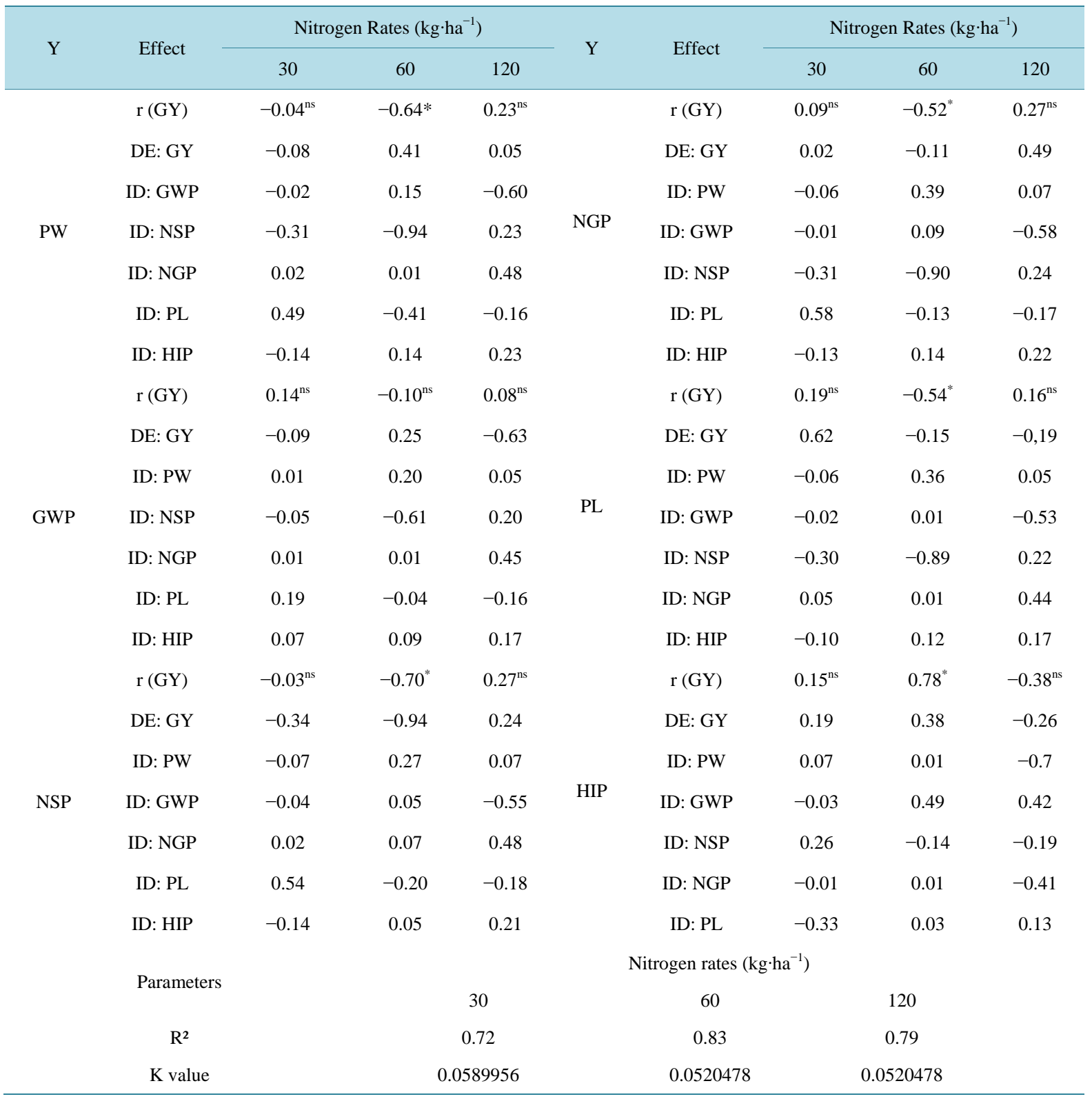

Y = variable; $\mathrm{GY}$ = grain yield $\left(\mathrm{kg} \cdot \mathrm{ha}^{-1}\right)$; $\mathrm{PW}=$ panicle weight $(\mathrm{g})$; GWP = grain weight per panicle (g); NSP = number spikelet per panicle (n); NGP = number grains per panicle (n); PL = panicle length $(\mathrm{cm})$; HIP = harvest index panicle $\left(\mathrm{GWP} / \mathrm{PW} \mathrm{g} \cdot \mathrm{g}^{-1}\right)$. $\mathrm{R}=$ correlation; DE $=$ direct effect; IE = indirect effect; $\mathrm{R}^{2}=$ coefficient of determination; $\mathrm{k}=$ coefficient of linearization; *= Significant at $5 \%$ probability of error by the test; ns = not significant.

with direct effects on grain yield. [31] found positive correlations of grain yield with the panicle weight in various studied conditions. [10] concluded that the increase in the panicle weight comes mainly from the increase in the number grain per panicle, with little effect on the mean grain weight. In the same way, [2] found that the number grains per panicle not interfere the grain weight, indicating independent action of these components on the inflorescence of the species.

\section{Conclusions}

The panicle weight and grain weight per panicle showed greater sensitivity to change the rates of nitrogen.

Grain yield was favored by the direct effect of harvest index panicle and indirect by grain weight per panicle. 
In soybean/oat system, the grain weight per panicle showed greater efficiency in promoting positive direct effects on grain yield.

\section{Acknowledgements}

To CNPq, FAPERGS, CAPES and UNIJUí by the contribution of resources for the development of this research and by grants for Scientific and Technological Initiation and Research Productivity.

\section{References}

[1] Santos, H.P., Fontaneli, R.S., Pires, J., Lampert, E.A., Vagyas, A.M. and Verdi, A.C. (2014) Grain Yield and Agronomic Traits Soybean According to Crop Rotation Systems. Bragantia, 73, 263-273. http://dx.doi.org/10.1590/1678-4499.0136

[2] Alves, A.C. and Kist, V. (2010) Spikelet Composition in White Oat (Avena sativa L.). Revista Brasileira de Agrociência, 16, 29-33.

[3] Hawerroth, M.C., Silva, J.A.G., Souza, C.A., Oliveira, A.C., Luche, H.S., Zimmer, C.M., Hawerroth, F.J., Schiavo, J. and Sponchiado, J.C. (2015) Lodging Reduction in White Oat Using the Plant Growth Regulator Trinexapac-Ethyl. Pesquisa Agropecuária Brasileira, 50, 115-125. http://dx.doi.org/10.1590/S0100-204X2015000200003

[4] Mantai, R.D., Silva, J.A.G., Sausen, A.T.Z.R., Costa, J.S.P., Fernandes, S.B.V. and Ubessi, C. (2015) Efficiency in the Production of Biomass and Oat Grains by the Use of Nitrogen. Revista Brasileira Engenharia Agrícola e Ambiental, 19, 343-349. http://dx.doi.org/10.1590/1807-1929/agriambi.v19n4p343-349

[5] Ma, B.L., Wu, T.Y., Tremblay, N., Deen, W., McLaughlin, N.B., Morrisnon, M.J. and Stewart, G. (2010) On-Farm Assessment of the Amount and Timing of Nitrogen Fertilizer on Ammonia Volatilization. Agronomy Journal, 102, 134-144. http://dx.doi.org/10.2134/agronj2009.0021

[6] Viola, R., Benin, G., Cassol, L.C., Pinnow, C., Flores, M.F. and Bornhofen, E. (2013) Green Manure and Nitrogen Fertilization in the Spring Wheat Under No-Tillage. Bragantia, 72 90-100. http://dx.doi.org/10.1590/S0006-87052013005000013

[7] Siqueira Neto, M., Piccolo, M.C., Venzke Filho, S.P., Feigl, B.J. and Cerri, C.C. (2010) Mineralization and Denitrification of Soil Nitrogen Under No-Tillage system. Bragantia, 69, 923-936. http://dx.doi.org/10.1590/S0006-87052010000400019

[8] Yasin, A.B. and Singh, S. (2010) Correlation and Path Coefficient Analysis in Sunflower. Journal of Plant Breeding and Crop Science, 2, 129-133.

[9] Silva, J.A.G., Arenhardt, E.G., Krüger, C.A.M.B., Lucchese, O.A., Metz, M. and Marolli, A. (2015) The Expression of the Components of Wheat Yield by Technological Class and Nitrogen Use. Revista Brasileira de Engenharia Agrícola e Ambiental, 19, 27-33.

[10] Hartwig, I., Carvalho, F.I.F., Oliveira, A.C., Silva, J.A.G., Lorencetti, C., Benin, G., Vieira, E.A., Bertan, I., Silva, G.O., Valério, I.P. and Schmidt, D.A.M. (2006) Phenotypic Correlations among Agronomic Characters in White Oat Diallel Crosses. Revista Brasileira de Agrociência, 12, 273-278.

[11] Kavalco, S.A.F., Figueiredo, R., Groli, E.L., Zimmer, C.M., Baretta, D., Tessmann, E.W., Magalhães Júnior, A.M. and Oliveira, A.C. (2014) Pathway Analyses in Wheat Genotypes under Waterlogging Stress. Semina: Ciências Agrárias, 35, 1683-1696. http://dx.doi.org/10.5433/1679-0359.2014v35n4p1683

[12] Nogueira, A.P.O., Sediyama, T., Sousa, A.L.B., Hamawaki, O.T., Cruz, C.D., Pereira, D.G. and Matsuo, E. (2012) Path Analysis and Correlations among Traits in Soybean Grown in Two Dates Sowing. Bioscience Journal, 28, 877888.

[13] Bartlett, M.S. (1937) Properties of Sufficiency and Statistical Test. Proceedings of the Royal Society: Series A, 160, 268-282.

[14] Mahalanobis, P.C. (1936) On the Generalized Distance in Statistics. Proceedings of the National Institute of Science of India, 2, 49-55.

[15] Singh, R.K. and Chaudary, B.D. (1979) Biometrical Methods in Quantitative Genetic Analyses. Kalyani Publisher, New Delhi, 304 p.

[16] Krüger, C.A.M.B., Silva, J.A.G., Medeiros, S.L.P., Dalmago, G.A., Sartori, C.O. and Schiavo, J. (2011) Plant Arrangement in the Expression of Yield Components of Canola. Pesquisa Agropecuária Brasileira, 46, 1448-1453. http://dx.doi.org/10.1590/S0100-204X2011001100005

[17] Cruz, C.D. (2013) GENES-A Software Package for Analysis in Experimental Statistics and Quantitative Genetics. Acta Scientiarum Agronomy, 35, 271-276. http://dx.doi.org/10.4025/actasciagron.v35i3.21251 
[18] Nascimento, F.M., Bicudo, S.J., Fernandes, D.M., Rodrigues, J.G.L., Fernandes, J.C. and Furtado, M.B. (2012) Time of Application and Doses of N Effects on the C/N Ratio of the Straw Cover and on Growth and Productivity of Maize Plants in a No-Tillage System. Científica, 40, 77-89. http://dx.doi.org/10.15361/1984-5529.2012v40n1p77+-+89

[19] Benin, G., Bornhofen, E., Beche, E., Pagliosa, E.S., Silva, C.L. and Pinnow, C. (2012) Agronomic Performance of Wheat Cultivars in Response to Nitrogen Fertilization Levels. Acta Scientiarum Agronomy, 34, 275-283. http://dx.doi.org/10.4025/actasciagron.v34i3.14468

[20] Wendling, A., Eltz, F.L.F., Cubilla, M.M., Amado, T.J.C., Mielniczuk, J. and Lovato, T. (2007) Nitrogen Fertilizer Recommendation for No-Till Wheat in Succession to Corn and Soybean in Paraguay. Revista Brasileira de Ciência do Solo, 31, 985-994. http://dx.doi.org/10.1590/S0100-06832007000500015

[21] De, K., Zhou, Q., Liu, W., Xu, C. and Wang, D. (2007) Effects of Nitrogen Application on the Yield and Quality of Oat in Qinghai-Tibet Plateau. Chinese Journal of Grassland, 29, 43-48.

[22] Braz, A.J.B.P., Silveira, P.M., Kliemann, H.J. and Zimmermann, F.J.P. (2006) Nitrogen Fertilization of Wheat Grown under No-Tillage after Different Cover Crops. Ciência e Agrotecnologia, 30, 193-198. http://dx.doi.org/10.1590/S1413-70542006000200001

[23] Cover, C., Federizzi, L.C. and Pacheco, M.T. (2011) Phenotypic and Genotypic Characterization Agronomic Traits in a Population of Recombinant Inbred Lines of Oats (Avena sativa L.). Ciência Rural, 41, 573-579. http://dx.doi.org/10.1590/S0103-84782011005000030

[24] Silva, J.A.G., Arenhardt, E.G. and Gewehr, E. (2014) Genetic Variability in the Search of Efficiency for Seed Production and Biomass of Sudan Grass. Revista Brasileira de Engenharia Agrícola e Ambiental, 18, 19-24. http://dx.doi.org/10.1590/S1415-43662014000100003

[25] Kurek, A.J., Carvalho, F.I.F., Cruz, P.J., Lorencetti, C., Cagynin, A. and Simioni, D. (2002) Variability in Fixed Genotypes of White Oats through Morphologic Traits. Revista Brasileira de Agrociência, 8, 13-17.

[26] Silva, J.A.G., Carvalho, F.I.F., Hartwig, I., Caetano, F.R., Bertan, I., Maia, L.C., Schmidt, D.A.M., Finatto, T. and Valério, I.P. (2007) Morphological Distance among Genotypes of Wheat with Absence and Presence of the "StayGreen” Trait. Ciência Rural, 37, 1261-1267. http://dx.doi.org/10.1590/S0103-84782007000500007

[27] Galarça, S.P., Lima, C.S.M., Silveira, G. and Rufato, A.R. (2010) Pearson Correlation and Path Analysis Identifying Variables for the Characterization of Pyrus communis L. Rootstock. Ciência e Agrotecnologia, 34, 860-869. http://dx.doi.org/10.1590/S1413-70542010000400010

[28] Vieira, E.A., Carvalho, F.I.F., Oliveira, A.C., Martins, L.F., Benin, G., Silva, J.A.G., Coimbra, J., Martins, A.F., Carvalho, M.F. and Ribeiro, G. (2007) Path Analysis among Primary and Secondary Yield Components in Wheat. Revista Brasileira de Agrociência, 13, 169-174.

[29] Junying, W., Jinghuil, L., Huaidong, W., Xiangqian, Z., Cuiling, Y. and Ying, W. (2010) Yield Performance of Different Oat Varieties and Correlation of Its Components. Journal of Inner Mongolia Finance and Economics College, 34, 176-184.

[30] Guercio, A.M.F.D. and Camargo, C.E.O. (2011) Heritability and Correlations among Agronomic Characteristics in Durum Wheat Hybrid Populations. Bragantia, 70, 19-24. http://dx.doi.org/10.1590/S0006-87052011000100004

[31] Marchioro, V.S., Carvalho, F.I.F., Oliveira, A.C., Cargnin, A., Lorencetti, C., Benin, G., Silva, J.A.G., Simioni, D., Hartwig, I. and Schimidt, D. (2004) Panicle Weight as a Criterion of Indirect Selection for Grain Yield Increase in Oat. Revista Ceres, 51, 683-692.

[32] Sant'Ana, E.V.P., Santos, A.B. and Silveira, P.M. (2011) The Efficiency of Use of Nitrogen Applied in Top Dressing in Irrigated Bean. Revista Brasileira de Engenharia Agrícola e Ambiental, 15, 458-462. http://dx.doi.org/10.1590/s1415-43662011000500004

[33] Guimarães, C.M., Stone, L.F. and Neves, P.C. (2008) Production Efficiency of Rice Cultivars with Phenotypic Diversity. Revista Brasileira de Engenharia Agrícola e Ambiental, 12, 465-470. http://dx.doi.org/10.1590/S1415-43662008000500004

[34] Wang, J., Yan, H. and Zhou, Q. (2009) Effects of Different Levels of Nitrogen and Potassium on Production Trait of Qingyin No.1 Oat. Pratacultural Science, 1, 1243-1251. 